OPEN ACCESS

Edited by:

Hanna Karakula-Juchnowicz,

Medical University of Lublin, Poland

Reviewed by:

Marcin Siwek,

Jagiellonian University, Medical

College, Poland

Renana Eitan,

Hebrew University Hadassah Medical

School, Israel

*Correspondence:

Marek Krzystanek

m.krzystanek@sum.edu.pl;

krzystanekmarek@gmail.com

†These authors have contributed equally to this work and share senior authorship

Specialty section

This article was submitted to

Psychopathology,

a section of the journal

Frontiers in Psychiatry

Received: 06 July 2021

Accepted: 16 August 2021

Published: 21 September 2021

Citation:

Krzystanek M, Surma S, Stokrocka M,

Romańczyk M, Przybyło J

Krzystanek N and Borkowski M (2021)

Tips for Effective Implementation of

Virtual Reality Exposure Therapy in

Phobias-A Systematic Review.

Front. Psychiatry 12:737351

doi: 10.3389/fpsyt.2021.737351

\section{Tips for Effective Implementation of Virtual Reality Exposure Therapy in Phobias-A Systematic Review}

\author{
Marek Krzystanek ${ }^{1 *}$, Stanisław Surma ${ }^{1}$, Małgorzata Stokrocka ${ }^{2 \dagger}$, Monika Romańczyk ${ }^{1}$, \\ Jacek Przybyło ${ }^{3}$, Natalia Krzystanek ${ }^{4}$ and Mariusz Borkowski ${ }^{2+}$ \\ ${ }^{1}$ Clinic of Psychiatric Rehabilitation, Department of Psychiatry and Psychotherapy, Faculty of Medical Sciences, Medical \\ University of Silesia in Katowice, Katowice, Poland, ${ }^{2}$ Department of Research and Development, Polfa Tarchomin, \\ Warszawa, Poland, ${ }^{3}$ Multispecialistic Voivodship Medical Clinic in Katowice, Katowice, Poland, ${ }^{4}$ Abramowski 18 th High \\ School, Katowice, Poland
}

Background: The high incidence of phobias and the limited accessibility of psychotherapy are the reasons for the search for alternative treatments that increase the availability of effective treatment. The use of virtual reality (VR) technology is an option with the potential to overcome the barriers in obtaining an effective treatment. VR exposure therapy (VRET) is based on a very similar rationale for in vivo exposure therapy. The study aimed to answer the question of how to perform exposure therapy in a virtual reality environment so that it is effective.

Methods: A systematic review of the literature, using PRISMA guidelines, was performed. After analysis of 362 records, 11 research papers on agoraphobia, 28 papers on social phobia and 10 about specific phobias were selected for this review.

Results: VRET in agoraphobia and social phobia is effective when performed from 8 to 12 sessions, on average once a week for at least $15 \mathrm{~min}$. In turn, the treatment of specific phobias is effective even in the form of one longer session, lasting 45-180 min. Head mounted displays are an effective technology for VRET. Increasing the frequency of sessions and adding drug therapy may shorten the overall treatment duration. The effectiveness of VRET in phobias is greater without concomitant psychiatric comorbidity and on the condition of inducing and maintaining in the patient an experience of immersion in the VR environment. Long-term studies show a sustained effect of VRET in the treatment of phobias.

Conclusion: A large number of studies on in VR exposure therapy in phobias allows for the formulation of some recommendations on how to perform VRET, enabling the effective treatment. The review also indicates the directions of further VRET research in the treatment of phobias.

Keywords: agoraphobia, social phobia, specific phobias, exposure therapy, virtual exposure therapy, VRET, virtual reality, VR 


\section{INTRODUCTION}

Phobic anxiety disorders are characterized by the occurrence of fear and anxiety in certain situations with little or no real threat, and a behavioral strategy to avoid those situations. Agoraphobia is an irrational fear of being out in the open space, in crowds, far from home, and of traveling alone. It is often accompanied or preceded by panic attacks. Social phobia, in turn, is an irrational fear of social situations and of avoiding them and specific phobias are fear and avoidance of specific objects or situations. All these phobias are common in the population. In the group of adults, the prevalence of specific phobias is estimated at $5-12 \%(1,2)$, social phobia at $2.4 \%$ (3), and agoraphobia at $2.3 \%$ (4). All phobias may lead to a significant disability and impairment in everyday functioning, with the loss of social and professional roles (5).

Evidence from prospective studies suggests that anxiety disorders should be viewed as a chronic disorder that begins in childhood, adolescence or early adulthood, with a peak in middle age and a decline in old age (5). According to the 2015 Global Burden of Disease Study, anxiety disorders ranks ninth in the list of the largest contributors to global disability (6). In the case of social phobia, $37.6 \%$ of people diagnosed after 12 months found severe role impairment in at least one life domain, and an average number of 24.7 days out of role per 1 year was recorded (3). In the case of panic disorder with agoraphobia, $84.7 \%$ of people diagnosed after 12 months described severe impairment of the social role, and in the case of agoraphobia without a history of panic disorder, but with panic attacks, 39.0\% reported severe impairment (7). These data show the urgent need to increase the availability of effective treatments.

The standard psychotherapy for agoraphobia and social phobia is cognitive-behavioral therapy (CBT) with the participation of a psychotherapist. Despite the convincing theoretical and empirical foundations, there appear to be barriers to the accessibility of this type of therapy in routine medical care. Neudeck and Einsle (8) mentioned structural barriers (e.g., time, insurance, or logistics) and barriers on the side of the therapist (e.g., negative attitude toward exposure therapy or insufficient knowledge of the method). These limitations hinder the accurate application of exposure techniques in clinical practice. These barriers pose a problem for patients, preventing them from receiving highly effective treatment (8). The use of virtual reality (VR) technology is an option with the potential to overcome these described difficulties. VR exposure therapy (VRET) is based on a very similar rationale for in vivo exposure therapy, however, in VR exposure, phobic stimuli are presented to the patient in a computer created artificial reality.

$\mathrm{VR}$ is a computer-generated reality that provides input to the user's sensory system and interacts with the user (9). Visual VR stimuli are presented through VR glasses [smartphone with 3D frames or a head-mounted display (HMD)] or by projection-based systems such as CAVE systems (automatic virtual environment in a cave), i.e., a room with up to six projection sides or Motek Caren system (10). The audio signal is input through speakers or head-phones, and optional tactile,

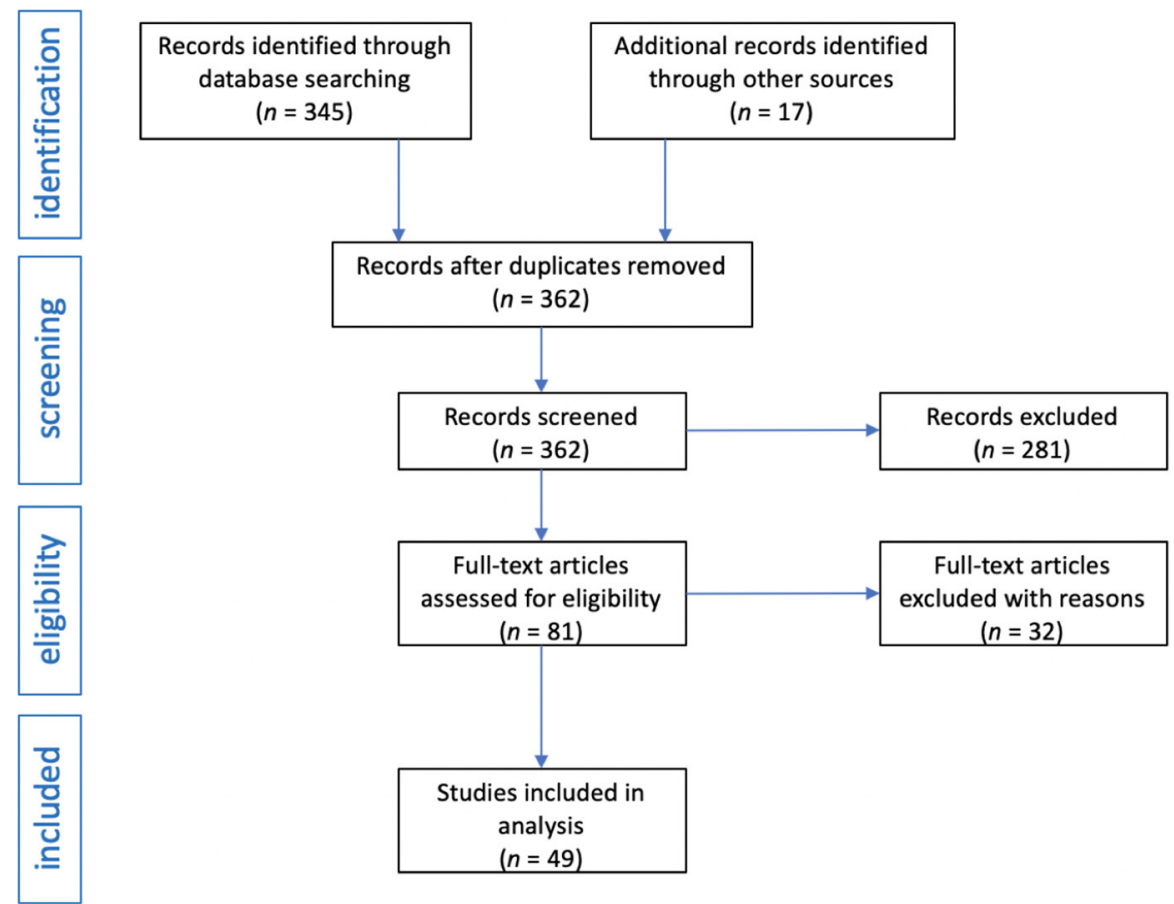

FIGURE 1 | Flow diagram of studies analysis and selection for review. 
TABLE 1 | Studies on the use of VR exposure therapy in agoraphobia.

\begin{tabular}{|c|c|c|c|c|c|c|}
\hline References & $n$ & $\begin{array}{l}\text { QATQS } \\
\text { (points) }\end{array}$ & $\begin{array}{l}\text { Characteristics of } \\
\text { participants }\end{array}$ & Intervention used & Results & Conclusions \\
\hline North et al. (20) & 60 & 2 & $\begin{array}{l}\text { Controlled clinical trial in } \\
\text { patients with agoraphobia. }\end{array}$ & $\begin{array}{l}\text { The subjects were assigned } \\
\text { to the therapeutic group } \\
\text { with the use of VR or to the } \\
\text { control group without } \\
\text { intervention. }\end{array}$ & $\begin{array}{l}\text { Desensitization to phobic } \\
\text { stimuli was demonstrated in } \\
\text { the group using VR. The } \\
\text { feeling of discomfort } \\
\text { decreased with successive } \\
\text { treatment sessions. }\end{array}$ & $\begin{array}{l}\text { If side effects occur during } \\
\text { VRET, they disappear in } \\
\text { subsequent sessions and } \\
\text { are not a reason for } \\
\text { dropping out of therapy. } \\
\text { Therapy with HMD. }\end{array}$ \\
\hline Vinelli et al. (22) & 12 & 2 & $\begin{array}{l}\text { Controlled clinical trial. } \\
\text { Patients with panic attacks } \\
\text { and agoraphobia. }\end{array}$ & $\begin{array}{l}\text { Subjects were randomly } \\
\text { divided into three groups: } \\
\text { receiving CBT using VR ( } 8 \\
\text { sessions) or conventional } \\
\text { therapy who had } \\
\text { experienced the traditional } \\
\text { CBT ( } 12 \text { sessions) or control } \\
\text { group without intervention. }\end{array}$ & $\begin{array}{l}\text { Clinical improvement was } \\
\text { achieved in the VR group } \\
\text { during } 8 \text { and not } 12 \\
\text { sessions as was the case } \\
\text { with conventional therapy. }\end{array}$ & $\begin{array}{l}\text { VRET is effective after } 8 \\
\text { sessions. The duration of } \\
\text { VRET may be shorter than } \\
\text { in vivo therapy. } \\
\text { VRET with HMD. }\end{array}$ \\
\hline Alcaniz et al. (23) & 1 & 3 & Patient with agoraphobia. & $\begin{array}{l}\text { Supporting psychological } \\
\text { therapy of agoraphobia at } \\
\text { home using VR on a } \\
\text { personal computer (PC). }\end{array}$ & $\begin{array}{l}\text { Not characterized. } \\
\text { Authors conclusion was that } \\
\text { he use of VR may be helpful } \\
\text { in the treatment } \\
\text { of agoraphobia. }\end{array}$ & $\begin{array}{l}\text { VRET can be performed on } \\
\text { a personal computer (PC). }\end{array}$ \\
\hline Pelissolo et al. (26) & 92 & 2 & $\begin{array}{l}\text { Randomized controlled } \\
\text { clinical trial. } \\
\text { Patients with panic attacks } \\
\text { and agoraphobia. }\end{array}$ & $\begin{array}{l}\text { Subjects were randomized } \\
\text { to either VR or classical CBT } \\
\text { or the control group. The } \\
\text { intervention consisted of } 12 \\
\text { therapy sessions. }\end{array}$ & $\begin{array}{l}\text { Clinical improvement was } \\
\text { shown in both active } \\
\text { treatment groups. There } \\
\text { were no statistically } \\
\text { significant differences in the } \\
\text { effectiveness of the therapy } \\
\text { between the two groups. }\end{array}$ & $\begin{array}{l}\text { VRET is effective with } 12 \\
\text { sessions of therapy. } \\
\text { Therapy with HMD. }\end{array}$ \\
\hline
\end{tabular}


TABLE 1 | Continued

\begin{tabular}{|c|c|c|c|c|c|c|}
\hline References & $n$ & $\begin{array}{l}\text { QATQS } \\
\text { (points) }\end{array}$ & $\begin{array}{l}\text { Characteristics of } \\
\text { participants }\end{array}$ & Intervention used & Results & Conclusions \\
\hline Malbos et al. (27) & 18 & 2 & $\begin{array}{l}\text { Randomized controlled } \\
\text { clinical trial. } \\
\text { Patients with agoraphobia. }\end{array}$ & $\begin{array}{l}\text { The subjects were classified } \\
\text { into two groups: therapy } \\
\text { with the use of VR or } \\
\text { therapy with the use of VR } \\
\text { and cognitive therapy. The } \\
\text { subjects were exposed to } 9 \\
\text { different virtual } \\
\text { environments. }\end{array}$ & $\begin{array}{l}\text { Questionnaires, behavioral } \\
\text { tests, and physiological } \\
\text { measurements indicated a } \\
\text { positive influence of VR. The } \\
\text { addition of cognitive therapy } \\
\text { did not bring any significant } \\
\text { additional benefits. }\end{array}$ & $\begin{array}{l}\text { For VRET to be effective, it } \\
\text { does not have to be } \\
\text { combined with conventional } \\
\text { CBT therapy. } \\
\text { Therapy with HMD. }\end{array}$ \\
\hline $\begin{array}{l}\text { Meyerbroeker et al. } \\
\text { (28) }\end{array}$ & 55 & 3 & $\begin{array}{l}\text { Randomized controlled } \\
\text { clinical trial. } \\
\text { Patients with panic attacks } \\
\text { and agoraphobia. }\end{array}$ & $\begin{array}{l}\text { Subjects were randomly } \\
\text { assigned to } 4 \text { sessions of } \\
\text { CBT and then to } 6 \text { sessions } \\
\text { using VR or } 6 \text { sessions with } \\
\text { in vivo exposure, or a control } \\
\text { group without intervention. }\end{array}$ & $\begin{array}{l}\text { Both CBT and VR therapy } \\
\text { were more effective than no } \\
\text { intervention. In the panic } \\
\text { disorder severity scale, in } \\
\text { vivo exposure CBT was } \\
\text { more effective than CBT } \\
\text { with VR. }\end{array}$ & $\begin{array}{l}\text { In vivo exposure may be } \\
\text { more effective than in VR } \\
\text { exposure in agoraphobia } \\
\text { with panic attacks. } \\
\text { Therapy with HMD or CAVE. }\end{array}$ \\
\hline Castro et al. (29) & 80 & 3 & $\begin{array}{l}\text { Clinical trial in patients with } \\
\text { chronic agoraphobia. }\end{array}$ & $\begin{array}{l}\text { Subjects were assigned to } \\
\text { either VR therapy or } \\
\text { conventional cognitive } \\
\text { behavioral therapy or } \\
\text { receiving treatment only. All } \\
\text { subjects received anti-stress } \\
\text { therapy. The observation } \\
\text { period was } 6 \text { months. }\end{array}$ & $\begin{array}{l}\text { All treatments were } \\
\text { statistically effective after } \\
\text { both treatment and } 6 \\
\text { months of follow-up. The } \\
\text { VR group showed clinical } \\
\text { improvement in most of the } \\
\text { variables measured during } \\
\text { observation. The in vivo } \\
\text { CBT group showed the } \\
\text { highest dropout rates. }\end{array}$ & $\begin{array}{l}\text { Patients treated with VRET } \\
\text { are less likely to discontinue } \\
\text { therapy than patients } \\
\text { treated with CBT. } \\
\text { Therapy with HMD. }\end{array}$ \\
\hline Pitti et al. (30) & 99 & 2 & $\begin{array}{l}\text { Randomized controlled } \\
\text { clinical trial. }\end{array}$ & $\begin{array}{l}\text { Subjects were randomly } \\
\text { assigned to receive } \\
\text { paroxetine and CBT, } \\
\text { paroxetine and CBT and } \\
\text { VRET, and paroxetine alone. } \\
\text { Both combined groups } \\
\text { received } 11 \text { CBT sessions, } \\
\text { and one group also received } \\
4 \text { VR therapy sessions. } \\
\text { Treatments were performed } \\
\text { in individual sessions once a } \\
\text { week for } 3 \text { months. }\end{array}$ & $\begin{array}{l}\text { The three treatment groups } \\
\text { showed statistically } \\
\text { significant improvement. For } \\
\text { some measures, the } \\
\text { combined treatment groups } \\
\text { showed greater } \\
\text { improvement. The group } \\
\text { exposed to VR showed } \\
\text { greater improvement in the } \\
\text { face of phobic stimuli. }\end{array}$ & $\begin{array}{l}\text { VRET in combination with } \\
\text { paroxetine is more effective } \\
\text { than either of these } \\
\text { methods alone. When } \\
\text { combined with paroxetine, } \\
\text { VRET is effective after } 4 \\
\text { sessions a week. } \\
\text { Therapy with HMD. }\end{array}$ \\
\hline
\end{tabular}

The risk of bias and study quality assessed with the Effective Public Health Practice Project's Quality Assessment Tool for Quantitative Studies (QATQS) was presented as the global rating for each publication (1-strong, 2-moderate, 3-weak).

or olfactory stimulation is possible but seldom provided. The goal of VR is to replace sensory stimuli from the real world and create an impression that a user is immersed in the real world experiencing. To interact with a user in real time, the VR system collects information about the user's position and head movements through sensors and input devices such as a head tracking system or a joystick.

To date, many clinical trials have been conducted, including randomized and controlled trials on the effectiveness of VRET in agoraphobia and social phobia. Due to a large amount of research, meta-analyzes assessing the above issue are also available in the literature. A summary of the most recent metaanalyzes on the use of VRET in the treatment of phobias is presented below.

In the meta-analysis by Wechsler et al. conducted in 2019 and involving 9 randomized and controlled clinical trials, the effectiveness of using VR in the treatment of agoraphobia and social phobia was assessed. It was shown that the use of VR in the treatment of social phobia compared to in vivo therapy did not bring any greater benefits (negative Hedges coefficient: $-0.50)$. In the case of agoraphobia, no statistically significant advantage of in vivo therapy over VR was found (negative Hedges coefficient: -0.01). The authors indicated the need to conduct further randomized controlled clinical trials with the use of VR in order to expand the knowledge in this field (11).

Similar results were obtained by Carl et al. in a meta-analysis of 30 studies on the use of VR in the treatment of various phobias, including social anxiety and agoraphobia (12). These researchers showed a large effect size for VR compared to those who were not subjected to the intervention (positive Hedges coefficient: 0.90). In addition, an average to large effect size for VR was found compared to the psychological placebo conditions (positive Hedges coefficient: 0.78). The comparison of VR with conventional in vivo therapy did not show significant differences 
TABLE 2 | Studies on the use of VR exposure therapy in social phobia.

\begin{tabular}{|c|c|c|c|c|c|c|}
\hline References & $n$ & $\begin{array}{l}\text { QATQS } \\
\text { (points) }\end{array}$ & $\begin{array}{l}\text { Characteristics of } \\
\text { participants }\end{array}$ & Intervention used & Results & Conclusions \\
\hline Harris et al. (31) & 14 & 2 & $\begin{array}{l}\text { Randomized controlled } \\
\text { clinical trial. } \\
\text { Students with social phobia. }\end{array}$ & $\begin{array}{l}\text { Four weekly sessions using } \\
\text { VR, each lasting } 15 \mathrm{~min} \text {. }\end{array}$ & $\begin{array}{l}\text { It was shown that the } \\
\text { applied intervention } \\
\text { decreased the level of } \\
\text { anxiety, feeling of } \\
\text { discomfort, and the heart } \\
\text { rate in the subjects. }\end{array}$ & $\begin{array}{l}\text { VRET is effective with } 4 \\
\text { sessions performed once a } \\
\text { week. The session may be } \\
\text { short, } 15 \text { min long. } \\
\text { Therapy with HMD. }\end{array}$ \\
\hline Klinger et al. (34) & 36 & 2 & $\begin{array}{l}\text { Controlled clinical trial. } \\
\text { Patients with social phobia. }\end{array}$ & $\begin{array}{l}\text { The subjects were assigned } \\
\text { to the group of VR therapy } \\
\text { or group CBT therapy. The } \\
\text { virtual environments related } \\
\text { to performance, intimacy, } \\
\text { mindfulness and } \\
\text { assertiveness. The } \\
\text { intervention lasted } 12 \text { weeks } \\
\text { and consisted of } 12 \\
\text { sessions. }\end{array}$ & $\begin{array}{l}\text { The results showed } \\
\text { significant improvement in } \\
\text { both treatment groups. }\end{array}$ & $\begin{array}{l}\text { VRET is effective after } 12 \\
\text { weekly sessions. } \\
\text { VRET on PC }\end{array}$ \\
\hline Anderson et al. (36) & 11 & 3 & $\begin{array}{l}\text { Single-arm clinical trial. } \\
\text { Patients with social phobia. }\end{array}$ & $\begin{array}{l}\text { Individual sessions, } \\
\text { including } 4 \text { sessions of } \\
\text { psychoeducation and } \\
\text { cognitive therapy and } 4 \\
\text { sessions of exposure } \\
\text { therapy using a virtual } \\
\text { audience presented on a } \\
\text { computer screen. A } \\
\text { therapist was available in } \\
\text { another room to answer } \\
\text { questions and summarize } \\
\text { up to } 10 \text { min after each } \\
\text { session. Three months } \\
\text { follow-up. }\end{array}$ & $\begin{array}{l}\text { All self-report measures of } \\
\text { social anxiety decreased; } \\
\text { the improvement was } \\
\text { maintained throughout the } \\
\text { follow-up period. } \\
\text { Participants reported that } \\
\text { they were satisfied with the } \\
\text { treatment, that they felt } \\
\text { better after treatment, and } \\
\text { that the computer program } \\
\text { was user-friendly. }\end{array}$ & $\begin{array}{l}\text { VRET is effective after } 4 \\
\text { sessions. } \\
\text { VRET on PC. }\end{array}$ \\
\hline Wallach et al. (37) & 112 & 2 & $\begin{array}{l}\text { Randomized controlled } \\
\text { clinical trial. } \\
\text { Patients with social phobia. }\end{array}$ & $\begin{array}{l}\text { The subjects were randomly } \\
\text { assigned to CBT in direct } \\
\text { contact or with the use of } \\
\text { VR or to the control group. } \\
\text { The intervention included } 8 \\
\text { sessions. }\end{array}$ & $\begin{array}{l}\text { Reduction of anxiety in the } \\
\text { group receiving active } \\
\text { therapy was observed. } \\
\text { During the study, twice as } \\
\text { many respondents } \\
\text { discontinued } \\
\text { cognitive-behavioral therapy } \\
\text { in direct contact than in VR } \\
\text { group. }\end{array}$ & $\begin{array}{l}\text { VRET is effective after } 8 \\
\text { sessions. } \\
\text { Therapy with HMD. }\end{array}$ \\
\hline
\end{tabular}


TABLE 2 | Continued

\begin{tabular}{|c|c|c|c|c|c|c|}
\hline References & $n$ & $\begin{array}{l}\text { QATQS } \\
\text { (points) }\end{array}$ & $\begin{array}{l}\text { Characteristics of } \\
\text { participants }\end{array}$ & Intervention used & Results & Conclusions \\
\hline Donahue et al. (38) & 20 & 1 & $\begin{array}{l}\text { Randomized controlled } \\
\text { clinical trial. } \\
\text { Patients with social phobia. }\end{array}$ & $\begin{array}{l}\text { Subjects were exposed to a } \\
\text { 4-min VR public speaking } \\
\text { after receiving either } \\
\text { quetiapine or placebo } \\
\text { (double-blind) an hour } \\
\text { earlier. A concurrent } \\
\text { placebo/quetiapine VR } \\
\text { exposition occurred } 1 \text { week } \\
\text { later. }\end{array}$ & $\begin{array}{l}\text { There was no significant } \\
\text { effect of quetiapine on the } \\
\text { outcome. However, } \\
\text { quetiapine was associated } \\
\text { with significantly increased } \\
\text { heart rate and somnolence. }\end{array}$ & $\begin{array}{l}4 \text { min VRET is less effective } \\
\text { than drug therapy. } \\
\text { Therapy with HMD. }\end{array}$ \\
\hline Robillard et al. (39) & 45 & 2 & $\begin{array}{l}\text { Randomized controlled } \\
\text { clinical trial. } \\
\text { Patients with social phobia. }\end{array}$ & $\begin{array}{l}\text { Patients were assigned to } \\
\text { either conventional CBT or } \\
\text { VR therapy or to a control } \\
\text { group. The intervention } \\
\text { included } 16 \text { sessions. }\end{array}$ & $\begin{array}{l}\text { The intervention groups } \\
\text { showed similar significant } \\
\text { reductions in social anxiety. }\end{array}$ & $\begin{array}{l}\text { VRET is effective after } 16 \\
\text { sessions. } \\
\text { No information about the } \\
\text { technic of VRET. }\end{array}$ \\
\hline Lister et al. (40) & 20 & 2 & $\begin{array}{l}\text { Randomized controlled } \\
\text { clinical trial. } \\
\text { Patients with phobia of } \\
\text { public speaking. }\end{array}$ & $\begin{array}{l}\text { The subjects were assigned } \\
\text { to the active intervention } \\
\text { group consisting of } 4 \mathrm{VR} \\
\text { sessions or to the control } \\
\text { group. }\end{array}$ & $\begin{array}{l}\text { Skin conductance and heart } \\
\text { rate were shown to } \\
\text { increase, suggesting that } \\
\text { the virtual reality intervention } \\
\text { was effective in triggering a } \\
\text { fear response. VRET was } \\
\text { found to reduce anxiety and } \\
\text { negative beliefs about public } \\
\text { speaking skills. }\end{array}$ & $\begin{array}{l}\text { VRET is effective after } 4 \\
\text { sessions. } \\
\text { Therapy with HMD. }\end{array}$ \\
\hline Wallach et al. (41) & 20 & 2 & $\begin{array}{l}\text { Randomized controlled } \\
\text { clinical trial. } \\
\text { Patients with social phobia. }\end{array}$ & $\begin{array}{l}\text { The subjects were assigned } \\
\text { to the intervention therapy } \\
\text { group using VR or cognitive } \\
\text { therapy or CBT or waiting } \\
\text { lists (WL). The intervention } \\
\text { consisted of } 12 \text { sessions. }\end{array}$ & $\begin{array}{l}\text { Cognitive therapy was no } \\
\text { better than VR in cognitive } \\
\text { measures, but was better } \\
\text { than VR in one behavioral } \\
\text { measure (LSAS fear). VR } \\
\text { was more effective than } \\
\text { cognitive therapy in terms of } \\
\text { one behavioral parameter } \\
\text { (reduction of fear in a } \\
\text { behavioral task). There were } \\
\text { no differences between the } \\
\text { three treatments and all } \\
\text { were superior to WL group. }\end{array}$ & $\begin{array}{l}\text { VRET is effective after } 12 \\
\text { sessions. } \\
\text { Therapy with HMD. }\end{array}$ \\
\hline Price et al. (42) & 41 & 3 & $\begin{array}{l}\text { Randomized controlled } \\
\text { clinical trial. } \\
\text { Patients with social phobia. }\end{array}$ & $\begin{array}{l}\text { The subjects were exposed } \\
\text { to } 8 \text { sessions during which } \\
\text { they were exposed to } \\
\text { various social situations in } \\
\text { VR: a conference room with } \\
5-100 \text { participants. Three } \\
\text { factors characterizing the } \\
\text { subject's immersion in } \\
\text { virtual reality were analyzed: } \\
\text { the sense of spatial } \\
\text { presence, commitment, and } \\
\text { the sense of reality. }\end{array}$ & $\begin{array}{l}\text { Various components of the } \\
\text { sense of reality were related } \\
\text { to the experience of fear and } \\
\text { the response to treatment } \\
\text { with VR. Efficacy was } \\
\text { significantly associated with } \\
\text { the highest anxiety ratings } \\
\text { reported by individuals } \\
\text { during the exposure. The } \\
\text { scale of involvement was } \\
\text { the only factor that was } \\
\text { significantly associated with } \\
\text { response to treatment. }\end{array}$ & $\begin{array}{l}\text { Eight sessions were } \\
\text { required for VRET to be } \\
\text { effective. The effectiveness } \\
\text { of treatment is related to the } \\
\text { sense of realism of the } \\
\text { exhibition environment. } \\
\text { Therapy with HMD. }\end{array}$ \\
\hline Cornwell et al. (43) & 32 & 2 & $\begin{array}{l}\text { A clinical trial involving } 16 \\
\text { healthy people and } 16 \text { with } \\
\text { social anxiety disorder. }\end{array}$ & $\begin{array}{l}\text { The subjects were } \\
\text { influenced by VR } \\
\text { representing a conference } \\
\text { room in which they were to } \\
\text { deliver a short speech. }\end{array}$ & $\begin{array}{l}\text { Patients with social phobia } \\
\text { reported greater stress and } \\
\text { anxiety than healthy people } \\
\text { throughout the procedure. }\end{array}$ & $\begin{array}{l}\text { The use of VR causes } \\
\text { similar reactions to those } \\
\text { accompanying reality, so } \\
\text { that technology can be } \\
\text { used in the treatment of } \\
\text { social phobia. } \\
\text { Therapy with } 3 d \text { Visor. }\end{array}$ \\
\hline
\end{tabular}


TABLE 2 | Continued

\begin{tabular}{|c|c|c|c|c|c|c|}
\hline References & $n$ & $\begin{array}{l}\text { QATQS } \\
\text { (points) }\end{array}$ & $\begin{array}{l}\text { Characteristics of } \\
\text { participants }\end{array}$ & Intervention used & Results & Conclusions \\
\hline $\begin{array}{l}\text { Heuett and Heuett } \\
\text { (44) }\end{array}$ & 120 & 3 & $\begin{array}{l}\text { Controlled clinical trial. } \\
\text { Students with phobia of } \\
\text { public speaking. }\end{array}$ & $\begin{array}{l}\text { The subjects were qualified } \\
\text { for exposure to public } \\
\text { speaking in virtual reality or } \\
\text { during video visualization, or } \\
\text { for a control group. }\end{array}$ & $\begin{array}{l}\text { In both groups of active } \\
\text { intervention, the feeling of } \\
\text { fear of public speaking was } \\
\text { reduced. Students who } \\
\text { were exposed to VR } \\
\text { reduced their fear of public } \\
\text { speaking more than } \\
\text { students exposed to video } \\
\text { visualization. }\end{array}$ & $\begin{array}{l}\text { It seems that the use of VR } \\
\text { in treating social phobia is } \\
\text { more effective than video } \\
\text { visualization. } \\
\text { Therapy with HMD. }\end{array}$ \\
\hline Safir et al. (45) & 49 & 2 & $\begin{array}{l}\text { Randomized controlled } \\
\text { clinical trial. } \\
\text { Patients with social anxiety. } \\
\text { A follow-up of the study by } \\
\text { Wallach et al. (37). }\end{array}$ & $\begin{array}{l}\text { Subjects were assigned to } \\
\text { either a VR or conventional } \\
\text { CBT intervention group or a } \\
\text { control group. The } \\
\text { intervention consisted of } 12 \\
\text { sessions. The observation } \\
\text { period was } 1 \text { year. }\end{array}$ & $\begin{array}{l}\text { After } 1 \text { year of observation, } \\
\text { it was shown that the } \\
\text { reduction of anxiety during } \\
\text { social appearances was still } \\
\text { maintained in both } \\
\text { intervention groups. }\end{array}$ & $\begin{array}{l}\text { The effectiveness of VRET } \\
\text { requires } 12 \text { sessions. } \\
\text { Therapy has long-term } \\
\text { success. } \\
\text { No information about the } \\
\text { technic of VRET. }\end{array}$ \\
\hline Anderson et al. (46) & 58 & 2 & $\begin{array}{l}\text { Randomized controlled } \\
\text { clinical trial. } \\
\text { Patients with social phobia. }\end{array}$ & $\begin{array}{l}\text { The subjects were assigned } \\
\text { to the actual exposure } \\
\text { group or the virtual or } \\
\text { pending exposure group. } \\
\text { People from active therapy } \\
\text { groups participated in } 8 \\
\text { sessions. The observation } \\
\text { period was } 12 \text { months. }\end{array}$ & $\begin{array}{l}\text { Subjects receiving active } \\
\text { therapy improved compared } \\
\text { to the waiting group. There } \\
\text { were no differences } \\
\text { between the active } \\
\text { treatments in any process or } \\
\text { outcome measure at any } \\
\text { time, nor were there } \\
\text { differences in the } \\
\text { achievement of partial or } \\
\text { complete remission. }\end{array}$ & $\begin{array}{l}\text { Eight sessions are required } \\
\text { for VRET to be effective. } \\
\text { VRET is effective in treating } \\
\text { social anxiety and the } \\
\text { improvement is sustained } \\
\text { for } 1 \text { year. No information } \\
\text { about the way VRET was } \\
\text { performed. }\end{array}$ \\
\hline Gebara et al. (47) & 21 & 2 & $\begin{array}{l}\text { Single-arm clinical trial. } \\
\text { Patients with social phobia. }\end{array}$ & $\begin{array}{l}\text { The subjects were exposed } \\
\text { to } 12 \text { sessions of } 50 \text { min } \\
\text { each, during which they } \\
\text { were exposed to VR. The } \\
\text { observation period was } 6 \\
\text { months. }\end{array}$ & $\begin{array}{l}\text { Improvement of social } \\
\text { anxiety was observed in all } \\
\text { scales and instruments } \\
\text { used, including the } \\
\text { follow-up period } 6 \text { months } \\
\text { after the end of treatment. } \\
\text { The average number of } \\
\text { sessions was seven as } \\
\text { participants quickly got } \\
\text { used to the process. }\end{array}$ & $\begin{array}{l}\text { VRET is effective on average } \\
\text { after } 7 \text { sessions. The effect } \\
\text { persists after the end of } \\
\text { treatment. } \\
\text { Therapy with HMD. }\end{array}$ \\
\hline $\begin{array}{l}\text { Kampmann et al. } \\
\text { (48) }\end{array}$ & 60 & 3 & $\begin{array}{l}\text { Randomized controlled } \\
\text { clinical trial. } \\
\text { Patients with social phobia. }\end{array}$ & $\begin{array}{l}\text { The subjects were assigned } \\
\text { to the in vivo or virtual } \\
\text { exposure group or to the } \\
\text { control group. The } \\
\text { intervention included } 10 \\
\text { sessions. }\end{array}$ & $\begin{array}{l}\text { Compared to the waiting } \\
\text { list, in active treatment } \\
\text { groups social anxiety, } \\
\text { perceived stress and beliefs } \\
\text { related to avoidant } \\
\text { personality decreased and } \\
\text { the duration of speech } \\
\text { increased. Subjects in the in } \\
\text { vivo exposure group but not } \\
\text { the VR group improved in } \\
\text { terms of fear of negative } \\
\text { judgment, speech } \\
\text { performance, overall } \\
\text { anxiety, depression, and } \\
\text { quality of life compared to } \\
\text { those on the waiting list. } \\
\text { During the observation } \\
\text { period, all improvements } \\
\text { were significant for the in } \\
\text { vivo exposure group. In the } \\
\text { case of VR, only the effect } \\
\text { of perceived stress was } \\
\text { significant. }\end{array}$ & $\begin{array}{l}\text { VRET may be slightly more } \\
\text { effective than in vivo } \\
\text { exposure. } \\
\text { Therapy with HMD. }\end{array}$ \\
\hline
\end{tabular}


TABLE 2 | Continued

\begin{tabular}{|c|c|c|c|c|c|c|}
\hline References & $n$ & $\begin{array}{l}\text { QATQS } \\
\text { (points) }\end{array}$ & $\begin{array}{l}\text { Characteristics of } \\
\text { participants }\end{array}$ & Intervention used & Results & Conclusions \\
\hline Anderson et al. (49) & 28 & 2 & $\begin{array}{l}\text { Randomized controlled } \\
\text { clinical trial. Patients with } \\
\text { social phobia. } \\
\text { A follow-up of the study by } \\
\text { Anderson et al. (46). }\end{array}$ & $\begin{array}{l}\text { Subjects completed } 8 \\
\text { therapy sessions using VR } \\
\text { or group conventional } \\
\text { therapy. }\end{array}$ & $\begin{array}{l}\text { It was shown that the } 54 \% \\
\text { of subjects no longer met } \\
\text { the diagnostic criteria for } \\
\text { social phobia and } 68 \% \\
\text { subjects reported that their } \\
\text { condition improved. }\end{array}$ & $\begin{array}{l}\text { For VRET to be effective, } 8 \\
\text { therapy sessions are } \\
\text { required. The effect lasts } \\
\text { after the end of the } \\
\text { treatment. } \\
\text { No information how VRET } \\
\text { was executed. }\end{array}$ \\
\hline $\begin{array}{l}\text { Stupar-Rutenfrans et } \\
\text { al. (50) }\end{array}$ & 35 & 3 & $\begin{array}{l}\text { Single arm clinical trial. } \\
\text { Students with fear of } \\
\text { speaking in front of an } \\
\text { audience. }\end{array}$ & $\begin{array}{l}\text { All subjects were exposed } \\
\text { over } 4 \text { weeks to } 8 \text { sessions } \\
\text { with the use of virtual reality } \\
\text { imitating a lecture hall: } \\
\text { without people and with a } \\
\text { small and large audience. }\end{array}$ & $\begin{array}{l}\text { It was shown that the fear of } \\
\text { speaking decreased } \\
\text { significantly after VRET } \\
\text { sessions, and the decrease } \\
\text { was strongest in } \\
\text { participants with initially high } \\
\text { levels of this anxiety. } \\
\text { Participants with moderate } \\
\text { to severe baseline anxiety } \\
\text { levels had different anxiety } \\
\text { patterns over time. }\end{array}$ & $\begin{array}{l}\text { The effectiveness of VRET } \\
\text { requires } 8 \text { sessions, } \\
\text { conducted twice a week. } \\
\text { The therapy is more } \\
\text { effective in people who have } \\
\text { a greater severity of anxiety } \\
\text { in their first VRET sessions. } \\
\text { Therapy with HMD. }\end{array}$ \\
\hline Bouchard et al. (51) & 59 & 2 & $\begin{array}{l}\text { Randomized controlled } \\
\text { clinical trial. } \\
\text { Patients with social phobia. }\end{array}$ & $\begin{array}{l}\text { Subjects were randomly } \\
\text { assigned to VR exposure ( } n \\
=17 \text { ), actual exposure ( } n= \\
22 \text { ) or waiting list ( } n=20) \text {. } \\
\text { Subjects receiving active } \\
\text { intervention participated in } \\
14 \text { weekly sessions. }\end{array}$ & $\begin{array}{l}\text { Social anxiety reduction was } \\
\text { found in the active therapy } \\
\text { group. Conducting therapy } \\
\text { with exposure to VR was } \\
\text { more effective than real } \\
\text { exposure. The beneficial } \\
\text { effects lasted } 6 \text { months. }\end{array}$ & $\begin{array}{l}\text { VRET is effective with } 14 \\
\text { sessions performed once a } \\
\text { week. } \\
\text { Therapy with HMD. }\end{array}$ \\
\hline Kim et al. (52) & 52 & 2 & $\begin{array}{l}\text { Controlled clinical trial. } \\
\text { Patients with social phobia } \\
(n=22) \text { and healthy } \\
\text { patients ( } n=30) \text {. }\end{array}$ & $\begin{array}{l}\text { The subjects were assigned } \\
\text { to a VR intervention group } \\
\text { or a control group. The } \\
\text { intervention included } 8 \\
\text { self-study sessions and } \\
\text { lasted } 2 \text { weeks. }\end{array}$ & $\begin{array}{l}\text { It was shown that the use of } \\
\text { VR was associated with a } \\
\text { reduction in anxiety and } \\
\text { social anxiety and with an } \\
\text { increase in speech time } \\
\text { during public speaking. }\end{array}$ & $\begin{array}{l}\text { VRET is effective after } 8 \\
\text { sessions. A mobile VR } \\
\text { application may be the } \\
\text { treatment option at home. } \\
\text { Therapy with HMD. }\end{array}$ \\
\hline Kovar (53) & 10 & 3 & $\begin{array}{l}\text { A comparative clinical trial } \\
\text { without randomization. } \\
\text { Patients with social phobia. }\end{array}$ & $\begin{array}{l}\text { The subjects were divided } \\
\text { into groups receiving } \\
\text { therapy using VR and a } \\
\text { group receiving } \\
\text { psychotherapy. The } \\
\text { intervention included } 8 \\
\text { sessions. }\end{array}$ & $\begin{array}{l}\text { Improvement in health and a } \\
\text { reduction in the feeling of } \\
\text { social anxiety was } \\
\text { demonstrated in both } \\
\text { therapeutic groups, but it } \\
\text { was more pronounced in } \\
\text { the group using VR. }\end{array}$ & $\begin{array}{l}\text { VRET is effective with } 8 \\
\text { sessions of therapy. VRET } \\
\text { may be more effective than } \\
\text { in vivo exposure. } \\
\text { Therapy with HMD. }\end{array}$ \\
\hline $\begin{array}{l}\text { Denizci Nazligul et } \\
\text { al. (54) }\end{array}$ & 14 & 2 & $\begin{array}{l}\text { Randomized controlled } \\
\text { clinical trial. } \\
\text { Patients with social phobia. }\end{array}$ & $\begin{array}{l}\text { The subjects were divided } \\
\text { into a group using VR and a } \\
\text { control group with } \\
\text { conventional CBT. The } \\
\text { intervention lasted } 4 \text { weeks } \\
\text { and included } 4 \text { sessions. }\end{array}$ & $\begin{array}{l}\text { Virtual reality and } \\
\text { psychotherapy have been } \\
\text { shown to be similarly } \\
\text { effective in reducing public } \\
\text { speaking anxiety. }\end{array}$ & $\begin{array}{l}\text { VRET is effective after } 4 \\
\text { sessions once a week. } \\
\text { Therapy with HMD. }\end{array}$ \\
\hline Geraets et al. (55) & 15 & 2 & $\begin{array}{l}\text { Clinical trial with one therapy } \\
\text { arm. } \\
\text { Patients with severe } \\
\text { social phobia. }\end{array}$ & $\begin{array}{l}\text { The subjects were exposed } \\
\text { to } 16 \text { sessions of } \\
\text { cognitive-behavioral therapy } \\
\text { with the use of VR. The } \\
\text { observation period was } 6 \\
\text { months. }\end{array}$ & $\begin{array}{l}\text { VRET reduced social anxiety } \\
\text { and improved the quality of } \\
\text { life of respondents. } \\
\text { During the observation } \\
\text { period, symptoms of } \\
\text { depression decreased. }\end{array}$ & $\begin{array}{l}\text { VRET is effective in therapy } \\
\text { involving } 16 \text { sessions. The } \\
\text { treatment effect is } \\
\text { maintained after the end of } \\
\text { treatment. } \\
\text { Therapy with HMD. }\end{array}$ \\
\hline Yuen et al. (56) & 26 & 2 & $\begin{array}{l}\text { A comparative clinical trial } \\
\text { without randomization. } \\
\text { Patients with social phobia. }\end{array}$ & $\begin{array}{l}\text { The subjects were assigned } \\
\text { to the intervention group } \\
\text { using videoconferencing } \\
\text { plus ACT (acceptance and } \\
\text { commitment therapy) or VR } \\
+ \text { ACT. The intervention } \\
\text { included } 6 \text { sessions. }\end{array}$ & $\begin{array}{l}\text { Both treatment groups } \\
\text { demonstrated a reduction in } \\
\text { anxiety during social } \\
\text { exposure. The satisfaction } \\
\text { of the respondents was also } \\
\text { comparable between the } \\
\text { groups. }\end{array}$ & $\begin{array}{l}\text { VRET is effective after just } 6 \\
\text { sessions. } \\
\text { VRET on PC. }\end{array}$ \\
\hline
\end{tabular}


TABLE 2 | Continued

\begin{tabular}{|c|c|c|c|c|c|c|}
\hline References & $n$ & $\begin{array}{l}\text { QATQS } \\
\text { (points) }\end{array}$ & $\begin{array}{l}\text { Characteristics of } \\
\text { participants }\end{array}$ & Intervention used & Results & Conclusions \\
\hline Kahlon et al. (57) & 27 & 3 & $\begin{array}{l}\text { A clinical trial in adolescents } \\
\text { with social anxiety disorder. }\end{array}$ & $\begin{array}{l}\text { Participants met for one } \\
\text { 90-min training session } 1 \\
\text { week after completing } \\
\text { online initial therapy } \\
\text { questionnaires. The } \\
\text { treatment protocol included } \\
\text { seven tasks of varying } \\
\text { difficulty, ranging from } 1 \text { to } \\
2 \text { min, each with little or no } \\
\text { preparation time. } \\
\text { Adolescents used VRET } \\
\text { only during the actual } \\
\text { exposure tasks to avoid } \\
\text { getting used to the virtual } \\
\text { environment. Follow-up was } \\
3 \text { months. }\end{array}$ & $\begin{array}{l}\text { The mixed-effect linear } \\
\text { model revealed a significant } \\
\text { reduction in social anxiety } \\
\text { symptoms (Cohen's } d= \\
\text { 1.53) before treatment, and } \\
\text { the improvement was } \\
\text { maintained throughout the } \\
\text { follow-up period. } \\
\text { Physiological data revealed } \\
\text { a slight increase in heart } \\
\text { rate during exposure tasks. } \\
\text { Based on feedback from } \\
\text { adolescents, the feasibility } \\
\text { of the intervention was } \\
\text { increased during the study. }\end{array}$ & $\begin{array}{l}\text { The effectiveness of VRET } \\
\text { requires appropriately } \\
\text { intensified stimuli so as not } \\
\text { to get use to digital } \\
\text { environment too quickly. } \\
\text { Therapy with HMD. }\end{array}$ \\
\hline Lindner et al. (58) & 23 & 2 & $\begin{array}{l}\text { A clinical trial. } \\
\text { Patients with social anxiety } \\
\text { in a routine medical } \\
\text { care setting. }\end{array}$ & $\begin{array}{l}\text { The subjects were exposed } \\
\text { to sessions in VR. Follow-up } \\
\text { was } 3 \text { months. }\end{array}$ & $\begin{array}{l}\text { There was a significant } \\
\text { decrease in public speaking } \\
\text { anxiety after the first 3-h } \\
\text { session. Multilevel modeling } \\
\text { of in-session process } \\
\text { measurements confirmed } \\
\text { reduction of disastrous } \\
\text { expectations and stress and } \\
\text { the increase of quality of } \\
\text { performance. Adherence to } \\
\text { the online transition } \\
\text { program that followed in } \\
\text { vivo exposure was relatively } \\
\text { poor, but symptoms } \\
\text { continued to decrease. No } \\
\text { changes were observed } \\
\text { during the 3-month } \\
\text { follow-up period. }\end{array}$ & $\begin{array}{l}\text { VRET may be an effective } \\
\text { form of continuing therapy } \\
\text { in vivo. } \\
\text { Therapy with HMD. }\end{array}$ \\
\hline
\end{tabular}

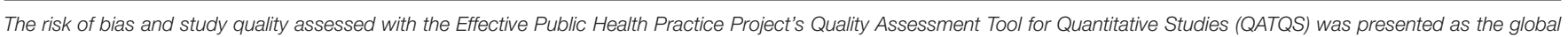
rating for each publication (1-strong, 2-moderate, 3-weak).

in the size of the effects (negative Hedges coefficient: -0.07). These results were relatively consistent across all analyzed disorders and they indicate that VR is effective and equal to conventional in vivo therapy as a medium for treating phobias (12).

In the most recent meta-analysis of 22 clinical trials with 703 participants by Horigome et al. the effectiveness of the use of VR in the treatment of social phobia was analyzed (13). The effectiveness of VR in treating social phobia was shown to be significant and sustained over a long observation period. Compared to in vivo exposure, the effectiveness of VR was similar after the intervention, but decreased in subsequent observation. The dropout rates of the participants showed no significant difference from the in vivo exposure results. Thus, the authors stated that VR is an acceptable method of treating patients with social phobia and has a significant long-term effect, although it is possible that its effectiveness will be reduced during long-term follow-up compared to conventional therapy.
Regarding the effectiveness of VRET in the treatment of specific phobias, a meta-analysis by Parsons and Rizzo (14) included 21 clinical trials involving 300 patients. VRET has been shown to be effective in reducing the symptoms of anxiety and phobias, especially in well-selected patients. The authors concluded that the use of VRET is effective in the treatment of anxiety and several specific types of phobias like social phobia, arachnophobia, acrophobia, agoraphobia, and aviophobia (14).

The impact of VRET on the behavior of patients with specific types of phobias in the real environment was also the subject of a meta-analysis of 14 studies conducted by Morina et al. (15). Behavioral evaluation results after treatment and during follow-up showed no significant differences between VRET and in vivo exposure ( $g=-0.09$ and 0.53 , respectively). The authors concluded that VRET cause significant changes in behavior in real-world situations (15). Also, in the last systematic review by Botella et al. (16), which included 11 randomized clinical trials, the effectiveness of using VRET in the treatment or support of the treatment of various types of phobias was assessed and found that 
TABLE 3 | Studies on the use of VR exposure therapy in specific phobias.

\begin{tabular}{|c|c|c|c|c|c|c|}
\hline References & $\boldsymbol{n}$ & $\begin{array}{l}\text { QATQS } \\
\text { (points) }\end{array}$ & $\begin{array}{l}\text { Characteristics of } \\
\text { participants }\end{array}$ & Intervention used & Results & Conclusions \\
\hline Triscari et al. (59) & 65 & 3 & $\begin{array}{l}\text { Randomized controlled } \\
\text { clinical trial in patients with } \\
\text { aerophobia. }\end{array}$ & $\begin{array}{l}\text { The subjects were } \\
\text { randomized into } \\
\text { three groups: } \\
\text { - CBT ( } n=22) \\
\text { - CBT + combined with eye } \\
\text { movement desensitization } \\
\text { and reprocessing therapy } \\
\text { (CBT-EMDR) ( } n=22) \\
\text { - CBT + VRET } \\
\text { - } 10 \text { sessions of } 2 \mathrm{~h} \\
\text { - Sessions 1-3: } \\
\text { psychoeducation, } \\
\text { cognitive and behavioral } \\
\text { techniques and relaxation } \\
\text { techniques. Flying } \\
\text { education } \\
\text { - Sessions 4-6: specific to } \\
\text { each treatment group } \\
\text { - Sessions } 7-10: \text { visit to the } \\
\text { faith of flight control, flight } \\
\text { simulation, and } \\
\text { airplane flight. }\end{array}$ & $\begin{array}{l}\text { All groups showed a } \\
\text { reduction in the fear of } \\
\text { flying. The performance } \\
\text { measurements maintained a } \\
\text { significant effect after the } \\
\text { 1-year follow-up period. }\end{array}$ & $\begin{array}{l}10 \text { VRET sessions } \\
\text { combined with exposition in } \\
\text { vivo. } \\
\text { No information about the } \\
\text { used device. }\end{array}$ \\
\hline Levy et al. (60) & 6 & 3 & $\begin{array}{l}\text { Single arm intervention } \\
\text { clinical trial including } \\
\text { acrophobic patients. }\end{array}$ & $\begin{array}{l}\text { Patients were exposed to } \\
\text { six sessions (two sessions } \\
\text { per week) of VR exposure } \\
\text { therapy. The first three were } \\
\text { remote sessions, while the } \\
\text { last three were traditional } \\
\text { sessions with a therapist. } \\
\text { The anxiety level, heart rate, } \\
\text { presence, technical } \\
\text { difficulties, and therapeutic } \\
\text { alliance were analyzed. }\end{array}$ & $\begin{array}{l}\text { It was shown that anxiety, } \\
\text { presence, and therapeutic } \\
\text { alliance were comparable in } \\
\text { both VRET sessions and } \\
\text { traditional therapy with the } \\
\text { therapist. }\end{array}$ & $\begin{array}{l}\text { VRET is effective in } \\
\text { acrophobia after } 6 \text { sessions. } \\
\text { Therapy with HMD. }\end{array}$ \\
\hline Gujjar et al. (62) & 10 & 2 & $\begin{array}{l}\text { A controlled clinical trial } \\
\text { involving patients with } \\
\text { dental phobia. }\end{array}$ & $\begin{array}{l}\text { The subjects were assigned } \\
\text { to the VRET group or the } \\
\text { educational advice group. } \\
\text { The effectiveness of VRET } \\
\text { was assessed by comparing } \\
\text { the reduction in dental } \\
\text { anxiety scores (measured } \\
16 \text { times over the } 14 \text {-week } \\
\text { study period and after } 6 \\
\text { months of follow-up). }\end{array}$ & $\begin{array}{l}\text { It has been shown to reduce } \\
\text { the symptoms of dental } \\
\text { phobia assessed on the } \\
\text { Dental Anxiety scale and the } \\
\text { Dental Fear scale, and to } \\
\text { reduce behavior avoidance } \\
\text { in VRET. Of the nine people } \\
\text { who completed treatment, } \\
\text { six (four in the VRET group } \\
\text { and two in the education } \\
\text { group) no longer had dental } \\
\text { phobia after } 6 \text { months of } \\
\text { follow-up. }\end{array}$ & $\begin{array}{l}\text { Dental phobia resolves after } \\
14 \text { VRET sessions. } \\
\text { Therapy with HMD. }\end{array}$ \\
\hline
\end{tabular}


TABLE 3 | Continued

\begin{tabular}{|c|c|c|c|c|c|c|}
\hline References & $n$ & $\begin{array}{l}\text { QATQS } \\
\text { (points) }\end{array}$ & $\begin{array}{l}\text { Characteristics of } \\
\text { participants }\end{array}$ & Intervention used & Results & Conclusions \\
\hline da Costa et al. (63) & 13 & 3 & $\begin{array}{l}\text { Single arm intervention } \\
\text { clinical trial in women with } \\
\text { driving phobia. }\end{array}$ & $\begin{array}{l}\text { The respondents were } \\
\text { exposed to } 8 \text { sessions with } \\
\text { a computer game } \\
\text { containing car driving } \\
\text { scenarios covering several } \\
\text { road situations. Participants' } \\
\text { sense of presence, } \\
\text { subjective suffering, and } \\
\text { physiological responses } \\
\text { were assessed during the } \\
\text { eight VRET exposures. } \\
\text { Participants' clinical } \\
\text { features, cognitive abilities, } \\
\text { and quality of life were also } \\
\text { analyzed. }\end{array}$ & $\begin{array}{l}\text { After VRET, there was a } \\
\text { reduction in the incidence of } \\
\text { distorted thoughts and state } \\
\text { anxiety scores, as well as a } \\
\text { slight improvement in quality } \\
\text { of life. The subjective results } \\
\text { of the discomfort, heart rate } \\
\text { variability, and sense of } \\
\text { presence scores confirmed } \\
\text { that there was a sense of } \\
\text { presence in the VRE } \\
\text { environment. }\end{array}$ & $\begin{array}{l}\text { VRET is effective in } \\
\text { dromophobia after } 8 \\
\text { sessions. } \\
\text { VRET on PC. }\end{array}$ \\
\hline Gujjar et al. (64) & 30 & 1 & $\begin{array}{l}\text { Single-blind, randomized } \\
\text { controlled clinical trial in } \\
\text { patients with dental phobia. }\end{array}$ & $\begin{array}{l}\text { Patients were randomized } \\
\text { to VRET or an information } \\
\text { booklet. A single VRET } \\
\text { session with five scenarios } \\
\text { was used. The measures of } \\
\text { anxiety were assessed } \\
\text { before and after the } \\
\text { intervention as well as } 1 \\
\text { week after and } 3 \text { and } 6 \\
\text { months after. }\end{array}$ & $\begin{array}{l}\text { It was shown that only } \\
\text { patients in the VRET group } \\
\text { showed a significant } \\
\text { reduction in dental anxiety. }\end{array}$ & $\begin{array}{l}\text { VRET is effective after } 1 \\
\text { session with an in VR } \\
\text { exposure of } 45 \text { min in which } \\
5 \text { different phobic scenarios } \\
\text { were performed. } \\
\text { Therapy with HMD. }\end{array}$ \\
\hline Miloff et al. (65) & 100 & 2 & $\begin{array}{l}\text { Randomized clinical trial in } \\
\text { patients with } \\
\text { arachnophobia. }\end{array}$ & $\begin{array}{l}\text { Patients were randomized } \\
\text { to one session of standard } \\
\text { in vivo therapy or VRET } \\
\text { The subjects were assessed } \\
\text { using the behavioral } \\
\text { approach evaluation test, a } \\
\text { scale self-assessment of } \\
\text { fear of spiders, depression, } \\
\text { and quality of life before and } \\
\text { after treatment, as well as } \\
\text { after } 3 \text { and } 12 \text { months. }\end{array}$ & $\begin{array}{l}\text { Behavioral avoidance and } \\
\text { reported fear were } \\
\text { significantly reduced in both } \\
\text { groups after treatment } \\
\text { discontinuation, with VRET } \\
\text { approaching the strong } \\
\text { treatment benefit of } \\
\text { standard in vivo therapy } \\
\text { over time. }\end{array}$ & $\begin{array}{l}\text { VRET is effective in } \\
\text { arachnophobia after just } \\
\text { one session, lasting } 3 \mathrm{~h} \text {. The } \\
\text { effect lasts after the end of } \\
\text { the therapy. } \\
\text { Therapy with HMD. }\end{array}$ \\
\hline Kaussner et al. (66) & 14 & 2 & $\begin{array}{l}\text { Randomized clinical trial in } \\
\text { patients with fear of driving } \\
\text { a car. }\end{array}$ & $\begin{array}{l}\text { The subjects were } \\
\text { randomized to VRET or } \\
\text { waiting. The intervention } \\
\text { included a medical and } \\
\text { psychotherapeutic } \\
\text { examination, two } \\
\text { preparatory sessions with a } \\
\text { psychotherapist, five } \\
\text { sessions with VRET and a } \\
\text { behavior avoidance test } \\
\text { (BAT) in real traffic, a closing } \\
\text { session and two further } \\
\text { telephone assessments } \\
\text { after } 6 \text { and } 12 \text { weeks. }\end{array}$ & $\begin{array}{l}\text { The treatment helped to } \\
\text { overcome fear and avoid } \\
\text { driving. In the final BAT, all } \\
\text { patients mastered the } \\
\text { driving tasks they had } \\
\text { previously avoided, } 71 \% \\
\text { showed adequate driving } \\
\text { behavior as assessed by the } \\
\text { driving instructor, and } 93 \% \\
\text { could maintain treatment } \\
\text { success until the second } \\
\text { control phone call. }\end{array}$ & $\begin{array}{l}5 \text { VRET sessions are } \\
\text { effective in dromophobia. } \\
\text { The effect lasts after the end } \\
\text { of the treatment. } \\
\text { VRET was performed with } \\
\text { high-fidelity fixed base } \\
\text { driving simulator. The visual } \\
\text { system comprises five } \\
\text { image channels that provide } \\
\text { a view of } 300^{\circ} \text { horizontally } \\
\text { and } 47^{\circ} \text { vertically as well as } \\
\text { a four-channels } \\
\text { sound system. }\end{array}$ \\
\hline
\end{tabular}


TABLE 3 | Continued

\begin{tabular}{|c|c|c|c|c|c|c|}
\hline References & $n$ & $\begin{array}{l}\text { QATQS } \\
\text { (points) }\end{array}$ & $\begin{array}{l}\text { Characteristics of } \\
\text { participants }\end{array}$ & Intervention used & Results & Conclusions \\
\hline Jiang et al. (67) & 43 & 2 & $\begin{array}{l}\text { Randomized controlled } \\
\text { clinical trial in patients with } \\
\text { blood-injection-injury } \\
\text { phobia. }\end{array}$ & $\begin{array}{l}\text { Patients were randomized } \\
\text { to the group: } \\
\text { - VRET } \\
\text { - Waiting list. } \\
\text { One treatment session was } \\
\text { used and was followed for } 3 \\
\text { months. }\end{array}$ & $\begin{array}{l}\text { Medium to large differences } \\
\text { in catastrophic cognitions } \\
\text { (probability }[g=0.88] \text { and } \\
\text { cost }[g=0.66] \text { scores) were } \\
\text { shown in favor of VRET. } \\
\text { There were medium to large } \\
\text { differences in favor of VRET } \\
\text { in the post-injection anxiety } \\
\text { and trauma subscale (MBPI } \\
g=0.64-1.14 \text { ) } 1 \text { week after } \\
\text { treatment and after } 3 \\
\text { months of follow-up, and in } \\
\text { the MBPI syncope subscale } \\
\text { ( } g=0.84 \text { ) and injections } \\
\text { subscale medical anxiety } \\
\text { test }(g=0.63 \text { ) during } \\
\text { observation. }\end{array}$ & $\begin{array}{l}\text { One 90-min VRET session } \\
\text { is effective in treating } \\
\text { blood-injection-injury } \\
\text { phobia. } \\
\text { Therapy with HMD. }\end{array}$ \\
\hline
\end{tabular}

The risk of bias and study quality assessed with the Effective Public Health Practice Project's Quality Assessment Tool for Quantitative Studies (QATQS) was presented as the global rating for each publication (1-strong, 2-moderate, 3-weak).

applications using VRET have become an effective alternative that in terms of effectiveness can equal the results of traditional treatments for phobias (16).

The presented meta-analyzes confirm the effectiveness of VRET and its equivalence with in vivo exposure therapy. The authors decided to conduct their own review of studies to answer the question of how to perform exposure therapy in a virtual reality environment so that it is effective. The results of this literature review may provide clues for the planning of therapy protocols using VRET and for the construction of the VR environment for therapeutic means. They may also be considered to implement in subsequent projects of phobia exposure treatment using VRET.

\section{MATERIALS AND METHODS}

The review included clinical trials, as well as case series and case reports. The authors' assumption was that even in single case reports of patients treated with VRET, there may be data on VRET elements that affect the effectiveness of exposure therapy. PRISMA guidelines were used when preparing this systematic review (17). The criteria for including the study in the analysis were the presence of a diagnosis of agoraphobia, social phobia and specific phobias and VRET treatment. The analysis also included studies in which, apart from VRET, a different treatment method was used. Full-text publications available in English were included in the analysis. In each study, at least the baseline and endpoints of treatment efficacy had to be characterized.

The following medical databases were searched in the study: PubMed, Scopus, Web of Science, and Google Scholar (effective date 10/06/2021). The search was performed according to the PICO framework ( $\mathrm{P}$-patient, problem or population, I-intervention, C-comparison, control or comparator, O-outcomes). During our search, we used the following terms: "virtual reality" (Title/Abstract), "virtual exposure" (Title/Abstract), "agoraphobia" (Title/Abstract), "social phobia" (Title/Abstract), "social anxiety" (Title/Abstract); and "specific phobia” (Title/Abstract).

The review was conducted independently by two investigators. After obtaining 345 records from the medical databases searched, the same terms were entered in the Google search engine and an additional 17 publications were obtained. When duplicate records were removed, 173 records were obtained for further analysis. In the next stage, an initial selection was carried out, excluding meta-analyzes, reviews, mini-reviews, systematic reviews, letters to the editor, editorials, comments, and errata. This pre-selection resulted in 81 publications. An in-depth selection was then performed and publications with only abstracts, papers in a language other than English, studies not directly related to the topic, and studies with methodological errors or data gaps were excluded. Ultimately, 49 clinical trials were included in the systematic review. The flow diagram of the analysis is presented in Figure 1. 
To assess the risk of bias and study quality in quantitative studies, the Effective Public Health Practice Project's (EPHPP) Quality Assessment Tool for Quantitative Studies (QATQS) was used $(18,19)$. This tool enables quality evaluation of a wide range of study designs, including RCTs, observational studies with and without control groups and case studies. The instrument contains eight different sections, each with multiple questions: selection bias, study design, confounders, blinding, data collection methods, withdrawals and drop-outs, intervention integrity, and analyses. Each section receives a score of 1 (strong), 2 (moderate), or 3 (weak), and a final score is determined by the number of "weak" ratings. Strong rating is given to a study if there is no weak component score. Moderate rating is given with one weak component score. Weak rating is given with two or more component rating scores.

\section{RESULTS}

The tables below show the results of the systematic review of the literature on the use of VRET in the treatment of patients with agoraphobia (Table 1), social phobia (Table 2), and specific phobias (Table 3).

\section{DISCUSSION}

Taking for granted the previously demonstrated effectiveness of VRET in the treatment of phobias, the current review focuses on parameters regarding the duration of therapy, session duration, session frequency, combining VRET with other types of therapy as well as technology used in exposure therapy. It was assumed that the conditions of using VRET in studies in which in VR exposure proved to be an effective form of phobia treatment determined its effectiveness. They should be considered as guidelines for the development of protocols and applications for running VRET.

With regard to the number of sessions and the duration of therapy, as shown by the analysis of the literature in agoraphobia, the number of sessions should be from 8 to 12 . On the other hand, in social phobia, the number of sessions ensuring the effectiveness of VRET is more diverse. Its efficacy was demonstrated in therapies performed with one-time session (57), and the highest number of sessions performed with great success was 16 (39). Most often, however, the number of sessions giving the effectiveness of VRET in the treatment of social phobia was, similarly to the treatment of agoraphobia, from 8 to 12 sessions. In the treatment of specific phobias, short therapies, most often consisting of one VRET session, were preferred, although longer protocols, including up to 14 sessions, were also successfully used.

The duration of one VRET session varies greatly depending on the study. If a single session therapy is to be effective, the exposure must last at least $60 \mathrm{~min}$ (57). It seems that for VRET sessions to be effective, they must last at least $15-20 \mathrm{~min}(31,32)$, especially if at least 4 are performed during the therapy (31). As mentioned, VRET in specific phobias is most often conducted in the form of a one-time session, however, these sessions must be longer. Based on the analysis, the VRET session in specific phobia should not be shorter than $45 \mathrm{~min}$ (64), but most often they last longer, even up to $3 \mathrm{~h}(58,61,65,67)$.

The conducted literature analysis shows that in agoraphobia the effectiveness of therapy is ensured by performing an average of one in VR exposure per week. It is similar in VRET in social phobia, and it is most often performed once a week. Perhaps performing VRET more than once a week may shorten the overall duration of therapy. In one study, it lasted 3 days with two VRET sessions a day (33). The possibility of reducing the duration of VRET therapy by increasing the frequency of sessions, for example twice a day, is a promising direction for further research.

Regarding the technology used in VRET, the most common are head mounted displays. They were used in $71.4 \%$ of the analyzed studies. Literature review demonstrates greater effectiveness of HMD technology over 2D image viewing (44). Contemporary technology offers portable HMDs that enable convenient home therapy (52). Such a set can also be a smartphone with an application for VRET installed on it. It will certainly allow for increased availability in the future, and thus may popularize VRET in the treatment of phobias.

Regarding the combination of different treatment methods, although VRET is an effective method used in monotherapy (11-16), however, it may be much more effective when combined with pharmacotherapy (30). When VRET is used with pharmacotherapy, the number of sessions can be shortened [e.g., 4 sessions in agoraphobia; (30)]. There are still too few studies on the augmentation of pharmacological treatment with VRET to draw conclusions about the number of sessions, their frequency and duration of a single session. This is a topic that requires further research. In addition to pharmacotherapy, VRET can be combined with in vivo exposure therapy, either as a pre-phase to in vivo therapy or as a follow-up to it. Also, in this case, it is necessary to conduct research on the possibilities and indications for combining these two types of exposure treatment.

An important issue is compliance with the eligibility rules for the exposure treatment of phobias in VR. Improper qualification for treatment without excluding comorbidity reduces the effectiveness of VRET (14). The analyzed studies and previously conducted meta-analyzes indicate that VRET is an effective exposure therapy in the treatment of phobias, but, if in addition to phobia, a patient suffers from another mental disorder, the effectiveness of exposure therapy is lower (28). This indicates the importance of proper qualification for VRET and avoidance of psychiatric comorbidity in order to ensure its effectiveness.

For the effectiveness of VRET, it is important for the patient to feel real and immersed in the environment provided by in VR exposure therapy $(42,43)$. With regard to the sense of immersion in virtual reality, it has been shown to occur very quickly. After just 2 min of using VRET, patients feel the realism of the virtual world (21). An important condition for the effectiveness of VRET is also the way of its conduct so that the patient does not get used to the digital VR environment too quickly without habituation to phobic stimuli. A way to counteract this familiarization with the digital environment may be the creation of many scenarios for the development of the exhibition environment (64). Also, the greater intensity of phobic stimuli may make it difficult to 

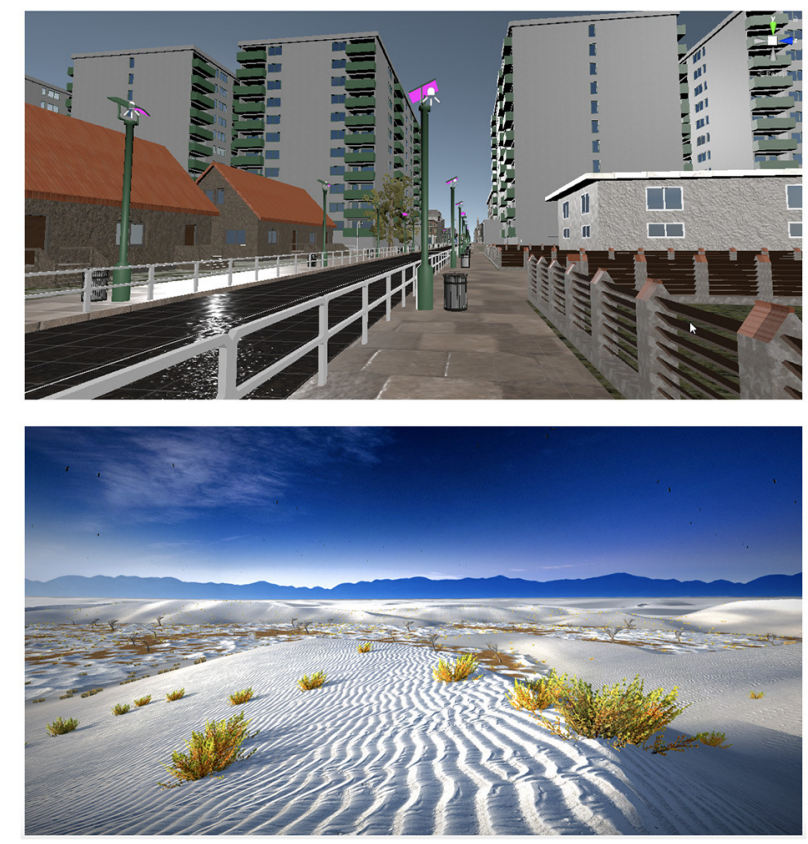

FIGURE 2 | The virtual exposure environment must provide the patient with a sufficient level of realism for the VRET to be effective. The photos show examples of high-quality computer graphics of opened space exposure environment from the VR voice-BOT application, developed (photos made by MK). Before treatment, the patient determines the type of phobic environment, as well as customizes it depending on his preferences, specifying the time of day, weather and the type of exposure. Exposure in a three-dimensional graphics environment is enriched with three-dimensional sound, recorded in real conditions. Next, VR voice-BOT, thanks to the speech recognition system, conducts an exposure hierarchy with the patient, increasing the intensity of phobic stimuli in the environment previously defined by the patient and asking him to determine the subjective level of distress in the subjective units of distress scale (SUDS). During the exposure, the patient uses his own smartphone with the application installed on it, and a joystick, and moves freely in a virtual environment.

get used to the digital environment and to lose the sense of immersion in real experience (57). This is indirectly indicated by the greater effectiveness of in VR exposure in people with greater severity of phobias (50). In the technology of conducting therapy by automated voice-BOT therapeutic applications with a speech recognition system, it is possible to create an algorithm that increases the level of exposure to phobic stimuli depending on the speed of habituation to the VR exposure environment (Figure 2). The evidence that it is possible to provide a full sense of reality in digital reality at least at the level of in vivo exposure are the reports that in VR exposure is more effective than in vivo $(48,53)$. The more virtual reality will imitate reality in terms of graphic resolution, a variety of scenarios and their dynamic adaptation to the patient's behavior, the greater will be its effectiveness.

As indicated by the conducted analysis, VRET exposure may give a lasting effect. However, long-term efficacy has not been studied for more than a year it seems satisfactory. Safir et al. (45) showed that after 1 year of clinical improvement, the reduction of social phobia symptoms is still maintained, regardless of whether the therapy was performed with VRET or in vivo exposure (42). Similar in other studies that conducted long-term follow-up of patients after treatment, it was possible to demonstrate the durability of the treatment effect after the completion of VRET $(46,47,49,51)$. This may indicate no need for maintenance therapy with VR. To confirm that, in subsequent studies of the effectiveness of phobia therapy with VRET, long-term follow-up of patients after the completion of VR therapy should be considered.

\section{CONCLUSIONS}

A large number of studies on in VR exposure therapy in phobias allows for the formulation of some recommendations on how to perform VRET, enabling the effective treatment. The conducted analysis of clinical trials allows to conclude that VRET in agoraphobia and social phobia is effective when performed from 8 to 12 sessions, on average once a week for at least $15 \mathrm{~min}$. In turn, the treatment of specific phobias is effective even in the form of one longer session, lasting 45$180 \mathrm{~min}$. Head mounted displays are an effective technology for VRET. Increasing the frequency of sessions and adding drug therapy may shorten the overall treatment duration. Moreover, the effectiveness of VRET in phobias is greater without psychiatric comorbidity and on the condition of generating and maintaining in the patient a sense of immersion in the VR environment.

Further studies should focus on the possibility of augmentation of pharmacological treatment with VRET, indications for combining in VR exposure with in vivo exposure, as well as the durability of VRET effects with possible maintenance therapy. In the future, it is also necessary to check the effectiveness of treatment protocols in which VRET is used more than once a week in terms of the possibility of reducing the total duration of treatment of phobias.

\section{DATA AVAILABILITY STATEMENT}

The original contributions presented in the study are included in the article/supplementary material, further inquiries can be directed to the corresponding author/s.

\section{AUTHOR CONTRIBUTIONS}

MK: conceptualization, data curation, and visualization. MK, SS, and MR: methodology. SS and MR: software. MK, MS, and MB: validation. SS, MR, MB, JP, MK, and NK: literature selection and analysis. MK, SS, MR, and JP: writing and original draft preparation. MK, $\mathrm{MB}$, SS, MR, and NK: writing, review, and editing. $\mathrm{MB}$ and MS: supervision and funding acquisition. All authors have read and agreed to the published version of the manuscript. 


\section{FUNDING}

This study received funding from Polfa Tarchomin S.A. The funder was not involved in the study design, collection, analysis, interpretation of data, the writing of this article, or the decision to submit it for publication.

\section{REFERENCES}

1. Ausin B, Muñoz M, Castellanos M, García S. Prevalence and characterization of specific phobia disorder in people over 65 years old in a madrid community sample (Spain) and its relationship to quality of life. Int J Environ Res Public Health. (2020) 17:1915. doi: 10.3390/ijerph17061915

2. Wardenaar KJ, Lim CCW, Al-Hamzawi AO, Alonso J, Andrade LH, Benjet C, et al. The cross-national epidemiology of specific phobia in the World Mental Health Surveys. Psychol Med. (2017) 47:174460. doi: $10.1017 /$ S0033291717000174

3. Stein DJ, Lim CCW, Roest AM, de Jonge P, Aguilar-Gaxiola S, AlHamzawi A, et al. The cross-national epidemiology of social anxiety disorder: data from the World Mental Health Survey Initiative. BMC Med. (2017) 15:143. doi: 10.1186/s12916-017-0889-2

4. Goodwin R, Faravelli C, Rosi S, Cosci F, Truglia E, de Graaf R, et al. The epidemiology of panic disorder and agoraphobia in Europe. Eur Neuropsychopharmacol. (2005) 15:435-43. doi: 10.1016/j.euroneuro.2005.04.006

5. Bandelow B, Michaelis S. Epidemiology of anxiety disorders in the 21st century. Dialogues Clin Neurosci. (2015) 17:32735. doi: 10.31887/DCNS.2015.17.3/bbandelow

6. GDB 2015 Disease and Injury Incidence an Prevalence Collaborators. Global, regional, and national incidence, prevalence, and years lived with disability for 310 diseases and injuries, 1990-2015: a systematic analysis for the Global Burden of Disease Study 2015. GBD 2015 Disease and Injury Incidence and Prevalence Collaborators. Lancet. (2016) 388:1545602. doi: 10.1016/S0140-6736(16)31678-6

7. Kessler RC, Chiu WT, Jin R, Ruscio AM, Shear K, Walters EE. The epidemiology of panic attacks, panic disorder, and agoraphobia in the National Comorbidity Survey Replication. Arch Gen Psychiatry. (2006) 63:415-24. doi: 10.1001/archpsyc.63.4.415

8. Neudeck P, Einsle F. Dissemination of exposure therapy in clinical practice: How to handle the barriers? In: Neudeck P, Wittchen H, editors. Exposure Therapy: Rethinking the Model - Refining the Method. New York, NY: Springer (2012). p. 23-34. doi: 10.1007/978-1-4614-3342-2_3

9. Diemer J, Pauli P, Mühlberger A. Virtual reality in psychotherapy. In: Wright JD, editor. International Encyclopedia of the Social and Behavioral Sciences. 2nd ed. Amsterdam: Elsevier (2015). p. 138-46. doi: 10.1016/B978-0-08-097086-8.21070-2

10. Krysta K, Wilczyński K, Paliga J, Szczesna A, Wojciechowska M, Martyniak E, et al. Implementation of the MOTEK CAREN system in behavioural therapy for patients with anxiety disorders. Psychiatr Danub. (2016) 28:116-20.

11. Wechsler T, Kümpers F, Mühlberger A. Inferiority or even superiority of virtual reality exposure therapy in phobias? A systematic review and quantitative meta-analysis on randomized controlled trials specifically comparing the efficacy of virtual reality exposure to gold standard in vivo exposure in agoraphobia, specific phobia, and social phobia. Front Psychol. (2019) 10:1758. doi: 10.3389/fpsyg.2019. 01758

12. Carl E, Stein A, Levihn-Coon A, Pogue JR, Rothbaum B, Emmelkamp P, et al. Virtual reality exposure therapy for anxiety and related disorders: a meta-analysis of randomized controlled trials. J Anxiety Disord. (2019) 61:27-36. doi: 10.1016/j.janxdis.2018.08.003

13. Horigome T, Kurokawa S, Sawada K, Kudo S, Shiga K, Mimura $M$, et al. Virtual reality exposure therapy for social anxiety disorder: a systematic review and meta-analysis. Psychol Med. (2020) 50:248797. doi: $10.1017 /$ S0033291720003785

\section{ACKNOWLEDGMENTS}

Voice VR BOT for VRET in agoraphobia described in the text was a project implemented from a Ministry of Science and Higher Education Grant (Dialog, No. 0075/DLG/2019/10).

14. Parsons TD, Rizzo AA. Affective outcomes of virtual reality exposure therapy for anxiety and specific phobias: a meta-analysis. J Behav Ther Exp Psychiatry. (2008) 39:250-61. doi: 10.1016/j.jbtep.2007.07.007

15. Morina N, Ijntema $\mathrm{H}$, Meyerbröker K, Emmelkamp PM. Can virtual reality exposure therapy gains be generalized to real-life? A meta-analysis of studies applying behavioral assessments. Behav Res Ther. (2015) 74:1824. doi: 10.1016/j.brat.2015.08.010

16. Botella C, Fernández-Álvarez J, Guillén V, García-Palacios A, Baños R. Recent progress in virtual reality exposure therapy for phobias: a systematic review. Curr Psychiatry Rep. (2017) 19:42. doi: 10.1007/s11920-017-0788-4

17. Moher D, Liberati A, Tetzlaff J, Altman DG, PRISMA Group. Preferred reporting items for systematic reviews and metaanalyses: the PRISMA statement. Ann Intern Med. (2009) 151:264-9. doi: 10.7326/0003-4819-151-4-200908180-00135

18. Thomas BH, Ciliska D, Dobbins M, Micucci S. A process for systematically reviewing the literature: providing the research evidence for public health nursing interventions. Worldviews Evid Based Nurs. (2004) 1:17684. doi: 10.1111/j.1524-475X.2004.04006.X

19. Armijo-Olivo S, Stiles CR, Hagen NA, Biondo PD, Cummings GG. Assessment of study quality for systematic reviews: a comparison of the Cochrane Collaboration Risk of Bias Tool and the Effective Public Health Practice Project Quality Assessment Tool: methodological research. J Eval Clin Pract. (2012) 18:12-8. doi: 10.1111/j.1365-2753.2010.01516.x

20. North MM, North SM, Coble JR. Effectiveness of virtual environment desensitization in the treatment of agoraphobia. Int J Virtual Reality. (1995) 1:25-34.

21. Moore K, Wiederhold BK, Wiederhold MD, Riva G. Panic and agoraphobia in a virtual world. Cyberpsychol Behav. (2002) 5:197-202. doi: 10.1089/109493102760147178

22. Vinelli F, Anolli L, Bouchard S, Wiederhold B, Zurloni V, Riva G. Experiential cognitive therapy in the treatment of panic disorders with agoraphobia: a controlled study. Cyberpsychol Behav. (2003) 6:3218. doi: 10.1089/109493103322011632

23. Alcaniz M, Botella C, Banos R, Perpina C, Rey B, Lozano JA, et al. Internetbased telehealth system for the treatment of agoraphobia. Cyberpsychol Behav. (2003) 6:355-8. doi: 10.1089/109493103322278727

24. Choi Y, Vincelli F, Riva G, Wiederhold B, Lee J, Park K. Effects of group experiential cognitive therapy for the treatment of panic disorder with agoraphobia. Cyberpsychol Behav. (2005) 8:387-93. doi: 10.1089/cpb.2005.8.387

25. Botella C, García-Palacios A, Villa H, Banos RM, Quero S, Alcañiz M, et al. Virtual reality exposure in the treatment of panic disorder and agoraphobia: a controlled study. Clin Psychol Psychother. (2007) 14:16475. doi: 10.1016/j.cbpra.2006.01.008

26. Pelissolo A, Zaoui M, Aguayo G, Yao SN, Roche S, Ecochard R, et al. Virtual reality exposure therapy versus cognitive behavior therapy for panic disorder with agoraphobia: a randomized comparison study. J Cyb Ther Rehab. (2012) 5:35-43.

27. Malbos E, Rapee RM, Kavakli MA. controlled study of agoraphobia and the independent effect of virtual reality exposure therapy. Aust N Z J Psychiatr. (2013) 47:160-8. doi: 10.1177/0004867412453626

28. Meyerbroeker K, Morina N, Kerkhof GA, Emmelkamp PMG. Virtual reality exposure therapy does not provide any additional value in agoraphobic patients: a randomized controlled trial. Psychother Psychosom. (2013) 82:1706. doi: 10.1159/000342715

29. Castro WP, Roca Sánchez MJ, Pitti González CT, Bethencourt JM, de la Fuente Portero JA, Marco RG. Cognitive-behavioral treatment and antidepressants 
combined with virtual reality exposure for patients with chronic agoraphobia. Int J Clin Health Psychol. (2014) 14:9-17. doi: 10.1016/S1697-2600(14)70032-8

30. Pitti CT, Peñate W, De La Fuente J, Bethencourt JM, Roca-Sánchez MJ, Acosta L, et al. The combined use of virtual reality exposure in the treatment of agoraphobia. Actas Esp Psiquiatr. (2015) 4343:133-41.

31. Harris SR, Kemmerling RL, North MM. Brief virtual reality therapy for public speaking anxiety. Cyberpsychol Behav. (2002) 5:543-50. doi: 10.1089/109493102321018187

32. Roy S, Klinger E, Legeron P, Lauer F, Chemin I, Nugues P. Definition of a VR-based protocol to treat social phobia. Cyberpsychol Behav. (2003) 6:411-20. doi: 10.1089/109493103322278808

33. Anderson P, Rothbaum B, Hodges LF. Virtual reality exposure in the treatment of social anxiety. Cogn Behav Pract. (2003) 10:2407. doi: $10.1016 /$ S1077-7229(03)80036-6

34. Klinger E, Bouchard S, Légeron P, Roy S, Lauer F, Chemin I, et al. Virtual reality therapy versus cognitive behavior therapy for social phobia: a preliminary controlled study. Cyber Psychol Behav. (2005) 8:7688. doi: $10.1089 / \mathrm{cpb} .2005 .8 .76$

35. Grillon H, Riquier F, Herbelin B, Thalmann D. Virtual reality as therapeutic tool in the confines of social anxiety disorder treatment. Int J Disabil Human Dev. (2006) 5:243-50. doi: 10.1515/IJDHD.2006.5.3.243

36. Anderson P, Zimand E, Schmertz S, Ferrer M. Usability and utility of a computerized cognitive-behavioral self-help program for public speaking anxiety. Cogn Behav Pract. (2007) 14:198207. doi: 10.1016/j.cbpra.2006.02.006

37. Wallach HS, Safir MP, Bar-Zvi M. Virtual reality cognitive behavior therapy for public speaking anxiety: a randomized clinical trial. Behav Modif. (2009) 33:314-38. doi: 10.1177/0145445509331926

38. Donahue CB, Kushner MG, Thuras PD, Murphy TG, Van Demark JB, Adson DE. Effect of quetiapine vs. placebo on response to two virtual public speaking exposures in individuals with social phobia. J Anxiety Disord. (2009) 23:3628. doi: 10.1016/j.janxdis.2008.12.004

39. Robillard G, Bouchard S, Dumoulin S, Guitard T, Klinger E. Using virtual humans to alleviate social anxiety: preliminary report from a comparative outcome study. Stud Health Technol Inform. (2010) 154:57-60.

40. Lister HA, Piercey CD, Joordens C. The effectiveness of 3-D video virtual reality for the treatment of fear of public speaking. J Cyber Ther Rehabil. (2010) 3:375-81.

41. Wallach H, Safir P, Bar-Zvi M. Virtual reality exposure versus cognitive restructuring for treatment of public speaking anxiety: a pilot study. Isr $J$ Psychiatry Relat Sci. (2011) 48:91-7.

42. Price M, Mehta N, Tone EB, Anderson PL. Does engagement with exposure yield better outcomes? Components of presence as a predictor of treatment response for virtual reality exposure therapy for social phobia. J Anxiety Disord. (2011) 25:763-70. doi: 10.1016/j.janxdis.2011.03.004

43. Cornwell BR, Heller R, Biggs A, Pine DS, Grillon C. Becoming the center of attention in social anxiety disorder: startle reactivity to a virtual audience during speech anticipation. J Clin Psychiatry. (2011) 72:9428. doi: 10.4088/JCP.09m05731blu

44. Heuett B, Heuett K. Virtual reality therapy: a means of reducing public speaking anxiety. Int J Humanit Soc Sci. (2011) 1:1-6.

45. Safir M, Wallach H, Bar-Zvi M. Virtual reality cognitive-behavior therapy for public speaking anxiety: one-year follow-up. Behav Modif. (2012) 36:23546. doi: 10.1177/0145445511429999

46. Anderson PL, Price M, Edwards SM, Obasaju MA, Schmertz SK, Zimand E, et al. Virtual reality exposure therapy for social anxiety disorder: a randomized controlled trial. J Consul Clin Psychol. (2013) 81:751. doi: 10.1037/a0033559

47. Gebara CM, Barros-Neto TPD, Gertsenchtein L, Lotufo-Neto F. Virtual reality exposure using three-dimensional images for the treatment of social phobia. Braz J Psychiatry. (2016) 38:24-9. doi: 10.1590/1516-4446-2014-1560

48. Kampmann IL, Emmelkamp PMG, Hartanto D, Brinkman WP, Zijlstra BJH, Morina N. Exposure to virtual social interactions in the treatment of social anxiety disorder: a randomized controlled trial. Behav Res Ther. (2016) 77:147-56. doi: 10.1016/j.brat.2015.12.016

49. Anderson PL, Edwards SM, Goodnight JR. Virtual reality and exposure group therapy for social anxiety disorder: results from a 4-6 year follow-up. Cog Ther Res. (2017) 41:230-6. doi: 10.1007/s10608-016-9820-y
50. Stupar-Rutenfrans S, Ketelaars L, van Gisbergen M. Beat the fear of public speaking: mobile $360^{\circ}$ video virtual reality exposure training in home environment reduces public speaking anxiety. Cyberpsychol Behav Soc Netw. (2017) 20:624-33. doi: 10.1089/cyber. 2017.0174

51. Bouchard S, Dumoulin S, Robillard G, Guitard T, Klinger É, Forget $\mathrm{H}$, et al. Virtual reality compared with in vivo exposure in the treatment of social anxiety disorder: a three-arm randomised controlled trial. $B r \quad J$ Psychiatry. (2017) 210:276-83. doi: 10.1192/bjp.bp.116. 184234

52. Kim HE, Hong YJ, Kim MK, Jung YH, Kyeong S, Kim JJ. Effectiveness of self-training using the mobile-based virtual reality program in patients with social anxiety disorder. Comput Human Behav. (2017) 73:6149. doi: 10.1016/j.chb.2017.04.017

53. Kovar I. Virtual reality as support of cognitive behavioral therapy in social anxiety disorder. IJASEIT. (2018) 8:1343-9. doi: 10.18517/ijaseit.8. 4.5904

54. Denizci Nazligul M, Yilmaz M, Gulec U, Yilmaz AE, Isler V, O'Connor $\mathrm{RV}$, et al. An interactive $3 \mathrm{~d}$ virtual environment to reduce the public speaking anxiety levels of novice software engineers. IET Softw. (2019) 13:1528. doi: 10.1049 /iet-sen. 2018.5140

55. Geraets CN, Veling W, Witlox M, Staring AB, Matthijssen SJ, Cath D. Virtual reality-based cognitive behavioural therapy for patients with generalized social anxiety disorder: a pilot study. Behav Cogn Psychother. (2019) 47:745-50. doi: 10.1017/S13524658190 00225

56. Yuen E, Goetter E, Stasio M, Ash P, Mansour B, McNally E, et al. A pilot of acceptance and commitment therapy for public speaking anxiety delivered with group videoconferencing and virtual reality exposure. J Contextual Behav Sci. (2019) 12:47-54. doi: 10.1016/j.jcbs.2019. 01.006

57. Kahlon S, Lindner P, Nordgreen T. Virtual reality exposure therapy for adolescents with fear of public speaking: a non-randomized feasibility and pilot study. Child Adolesc Psychiatry Ment Health. (2019) 13:47. doi: 10.1186/s13034-019-0307-y

58. Lindner P, Miloff A, Bergman C, Andersson G, Hamilton W, Carlbring P. Gamified, automated virtual reality exposure therapy for fear of spiders: a single-subject trial under simulated real-world conditions. Front Psychiatry. (2020) 11:116. doi: 10.3389/fpsyt.2020.00116

59. Triscari MT, Faraci P, Catalisano D, D'Angelo V, Urso V. Effectiveness of cognitive behavioral therapy integrated with systematic desensitization, cognitive behavioral therapy combined with eye movement desensitization and reprocessing therapy, and cognitive behavioral therapy combined with virtual reality exposure therapy methods in the treatment of flight anxiety: a randomized trial. Neuropsychiatr Dis Treat. (2015) 11:25918. doi: 10.2147/NDT.S93401

60. Levy F, Leboucher P, Rautureau G, Jouvent R. E-virtual reality exposure therapy in acrophobia: a pilot study. J Telemed Telecare. (2016) 22:21520. doi: 10.1177/1357633X15598243

61. Botella C, Pérez-Ara MÁ, Bretón-López J, Quero S, García-Palacios A, Baños RM. In vivo versus augmented reality exposure in the treatment of small animal phobia: a randomized controlled trial. PLoS ONE. (2016) 11:e0148237. doi: 10.1371/journal.pone.0148237

62. Gujjar KR, van Wijk A, Sharma R, de Jongh A. Virtual reality exposure therapy for the treatment of dental phobia: a controlled feasibility study. Behav Cogn Psychother. (2018) 46:367-73. doi: 10.1017/S13524658170 00534

63. Costa RTD, Carvalho MR, Ribeiro P, Nardi AE. Virtual reality exposure therapy for fear of driving: analysis of clinical characteristics, physiological response, and sense of presence. Braz J Psychiatry. (2018) 40:1929. doi: 10.1590/1516-4446-2017-2270

64. Gujjar KR, van Wijk A, Kumar R, de Jongh A. Efficacy of virtual reality exposure therapy for the treatment of dental phobia in adults: a randomized controlled trial. J Anxiety Disord. (2019) 62:100-8. doi: 10.1016/j.janxdis.2018.12.001

65. Miloff A, Lindner P, Dafgård P, Deak S, Garke M, Hamilton W, et al. Automated virtual reality exposure therapy for spider phobia vs. in-vivo 
one-session treatment: a randomized non-inferiority trial. Behav Res Ther. (2019) 118:130-40. doi: 10.1016/j.brat.2019.04.004

66. Kaussner Y, Kuraszkiewicz AM, Schoch S, Markel P, Hoffmann S, Baur-Streubel R, et al. Treating patients with driving phobia by virtual reality exposure therapy - a pilot study. PLoS ONE. (2020) 15:e0226937. doi: 10.1371/journal.pone.0226937

67. Jiang MYW, Upton E, Newby JM. A randomised wait-list controlled pilot trial of one-session virtual reality exposure therapy for blood-injectioninjury phobias. J Affect Disord. (2020) 276:636-45. doi: 10.1016/j.jad.2020. 07.076

Conflict of Interest: The authors declare that the research was conducted in the absence of any commercial or financial relationships that could be construed as a potential conflict of interest.
Publisher's Note: All claims expressed in this article are solely those of the authors and do not necessarily represent those of their affiliated organizations, or those of the publisher, the editors and the reviewers. Any product that may be evaluated in this article, or claim that may be made by its manufacturer, is not guaranteed or endorsed by the publisher.

Copyright (C) 2021 Krzystanek, Surma, Stokrocka, Romańczyk, Przybyło, Krzystanek and Borkowski. This is an open-access article distributed under the terms of the Creative Commons Attribution License (CC BY). The use, distribution or reproduction in other forums is permitted, provided the original author(s) and the copyright owner(s) are credited and that the original publication in this journal is cited, in accordance with accepted academic practice. No use, distribution or reproduction is permitted which does not comply with these terms. 